\title{
RODLETS FROM COMPRESSED MEDULLOSALEAN PLANT FOSSILS: CHEMICAL AND MORPHOLOGICAL STUDIES (LATE PENNSYLVANIAN SYDNEY COALFIELD, CANADA)
}

\author{
Erwin L. Zodrow ${ }^{1} \&$ Maria Mastalerz ${ }^{2}$
}

${ }^{1} 503$ Coxheath Road, Sydney, Nova Scotia, Canada B1R 1S1; zzodrovii@gmail.com

${ }^{2}$ Indiana Geological and Water Survey, Indiana University, Bloomington, Indiana, 47405 2208, U.S.A; mmastale@indiana.edu

\begin{abstract}
Fragmented compression specimens of medullosalean fronds have been voluminously described over the past 200 years. However, the literature on rodlets is scarce. We addressed the questions (i) of common occurrence in these fronds, (ii) what made the fronds so strong to bear such a biomassive load, and (iii) what is the chemical make up of rodlets that expressed as striae and ridges (medullosalean hallmark) occur on these fronds? Recovered were soluble and insoluble, black, round and flat, opaque or translucent rodlets that are up to $5 \mathrm{~mm}$ long and ca. 10-111 $\mu \mathrm{m}$ wide, and are typed as (i) transparent, (ii) insoluble, or (iii) soluble in Schulze's solution. In situ insoluble rodlets can be distinguished from associate coal and cuticle-free compression foliage and rachides by relatively high aromaticity and low aliphatics, although their chemical composition is unknown. Rodlets are presumably related to sclerenchymatous tissue in support of strength/stability of these sizeable medullosalean fronds.
\end{abstract}

Key words: Morphology, FTIR, rodlets, seed ferns, strength, Pennsylvanian.

\section{INTRODUCTION}

Seed-fern trees (Order Medullosales) inhabited the drier river banks or levees of the giant Carboniferous coal mires located near the palaeoequator, probably reaching heights 10-12 m, with megaphylls (fronds) that themselves could reach a length of $5 \mathrm{~m}$ or more. Extreme estimates of frond sizes were 20 m (summary: Raymond \& Phillips, 1983; Beeler, 1983), although a complete frond has never been collected for validation of these sizes. Considered must also be the large up to $120 \mathrm{~mm}$ long ovules these seed ferns carried that added an appreciable dead load until drop-off time. Although the infrared spectral methodology by which these large non-woody structures can theoretically be investigated for mechanical-strength/resistance is still in its infancy (D'Angelo \& Zodrow, 2018), instead directly accessible are rodlets for qualitative consideration. Rodlets have not been reported in place from medullosalean fronds, but they have been collected loose from coal seams (Lyons et al. 1982), shale above coal seams, coal balls (van Bergen et al. 1995), and from petrified medullosalean stems. Rodlets are presumably of organic composition, are described as being straight-linear structures of unknown natural length, although samples of up to $6,000 \mu \mathrm{m}$ long and ca. $100 \mu \mathrm{m}$ in diameter have been reported. They are round- or crescent-shaped, and may either be opaque (vitrain-like?) or translucent (resin-like?), where some have vescicular or channeled internal structure, e.g., Steidtmann (1944), Kosanke \& Harrison (1957).

Linear structures from a fusain-preserved medullosalean trunk that morphologically compared with rodlets were published by Zodrow et al. (2010) from the Late Pennsylvanian Sydney Coalfield (Figure 1A and B).

However, described for the first time are functional-group data of selected in situ rodlets from a medullosalean frond, although rodlets were generally recovered from a plethora of medullosalean compression rachides, petioles, and two trunks. It is premature to speculate on the role rodlets could play in advancing medullosalean taxonomy/ systematics.

\section{MATERIAL AND SAMPLING}

Since 1983, E. Zodrow has macerated and examined a large number of medullosalean compression material, especially rachides, that were collected 


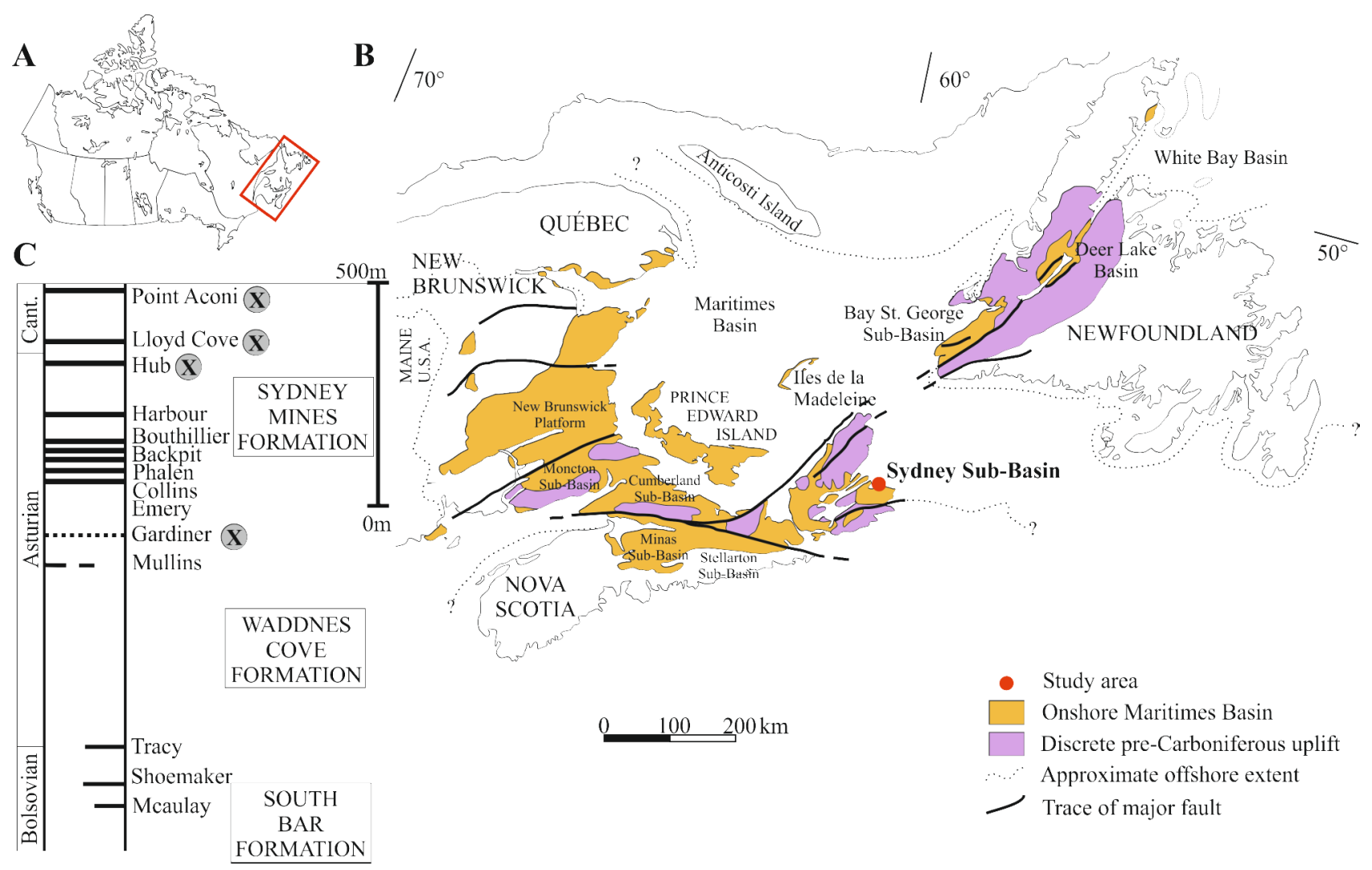

Figure1. Location map; A) Canada and Nova Scotia; B) the Maritimes Basin; C) Coal stratigraphy of the Sydney Coalfield.

from the roof shale of various coal seams of the Sydney Coalfield (Figure 1C), without paying much attention to the coaly 'splinters' that apparently formed the striae and that were mostly ignored by palaeobotanists. However, during the past 2 years attention was focused on occurrences, and distribution of rodlets in frond segments, and the slides that were prepared formed the basis for this communication. Although over 50 specimens were investigated, including some pinnules, Plate I, Figs. 1-6 only show a selection of the collections from roof rocks of the following coal seams: Point Aconi, coastal exposure; Lloyd Cove, open-pit mine; Hub, underground mine; and Gardiner, open-pit mine. Table 1 lists only some of the larger specimens that provided rodlet material. Although vitrinite reflectance values (Ro\%) that lend themselves to coal-rank interpretation are not available from the rodlets themselves, Ro\% of associate coal seams range between $0.65 \%$ to $0.75 \%$, implying minimal diagenetic intervention in the preservation process.
Sampling for rodlets is relatively uncomplicated but tedious and time consuming, and since they are quite thin they can easily be overlooked, even at 40x magnification. In the sampling process, compressions were (i) lifted directly from the rock matrix, or (ii) freed by $\mathrm{HF}(48 \%)$ digestion from the rock matrix that was first thinned to 500 to $800 \mu \mathrm{m}$. The thinning not only economized on HF usage, increasing safety, but also safe-guarded against dispersed rodlets. Collected sludge from the latter yielded rodlets by association (see Zodrow et al. 2012). However, the main effort focused on examining the compressions themselves, 'as is' samples, and on the macerated compressions which yielded rodlets in situ. The disadvantage of the maceration process is the potential loss of soluble rodlets, whereas 'as is' samples yielded both soluble and insoluble samples (see later). The reference collection of rodlet samples comprises 30 glass-covered micro slides. 

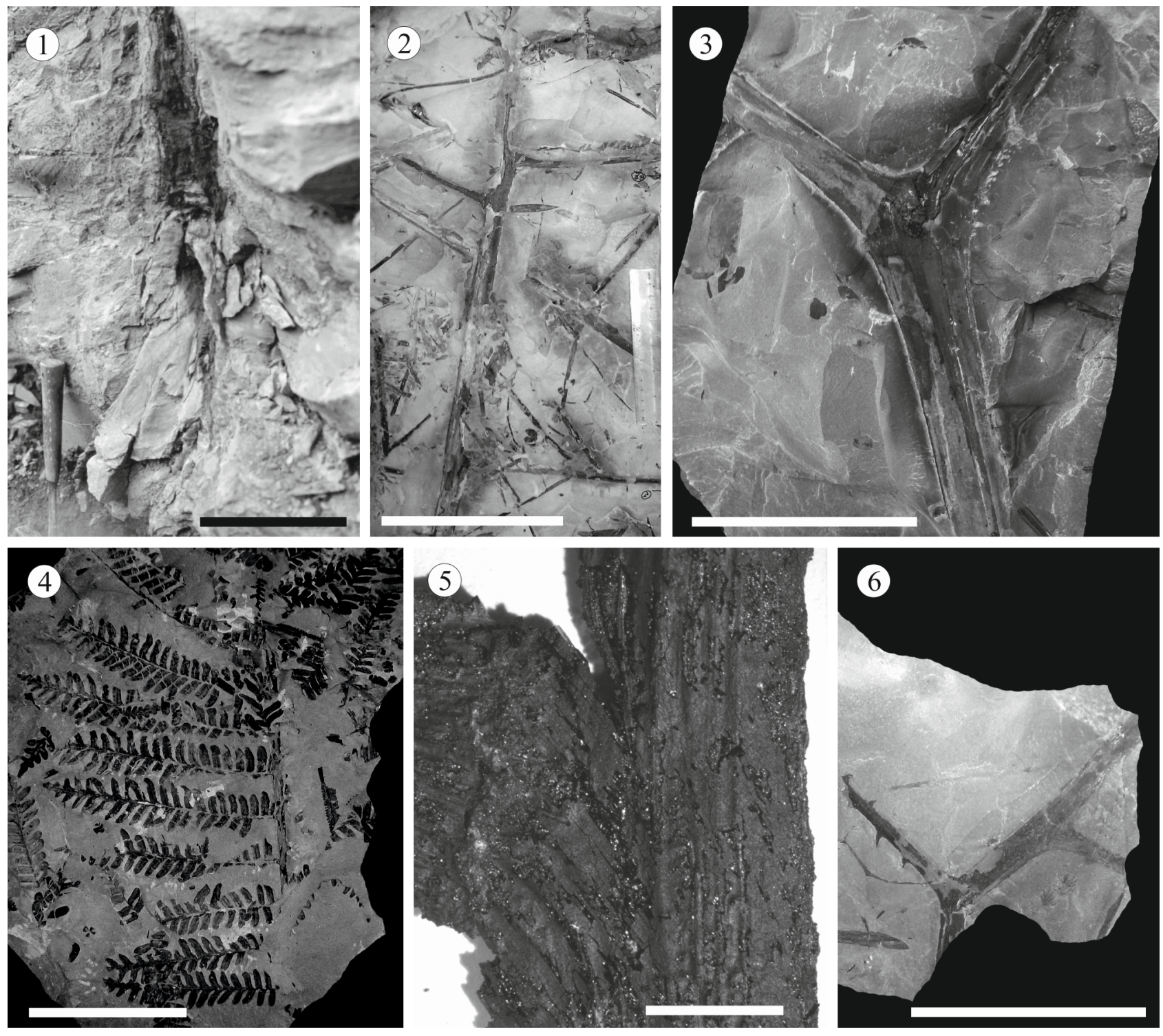

Plate I. A selection of the sampled larger medullosalean frond structures; 1) Tree fern in life position on the Lloyd Coal mire. The $100 \mathrm{~mm}$ trunk was sampled. See Table 1, 03-346, scale bar $300 \mathrm{~mm}$; 2) Possibly a quadripinnate frond architecture. The upper part was sampled, scale bar $150 \mathrm{~mm}$; 3) Basal dichotomy, presumably of Macroneuropteris scheuchzeri. 07-6/15-2, scale bar $150 \mathrm{~mm}$; 4) Alethopteris pseudograndinioides; see Plate II, Fig. 2. The main rachis was sampled. 003-328A, scale bar $150 \mathrm{~mm}$; 5) Neuropteris ovata main rachis (horizontal) and branching rachis. 3-248, scale bar $5 \mathrm{~mm}$; 6) Undetermined frond architecture, presumably Linopteris obliqua (Zodrow et al. 2007). 06-06/22-5, scale bar $150 \mathrm{~mm}$.

\section{METHOD}

Micro-FTIR is the appropriate tool for obtaining chemical information from the small rodlets that are $10-180 \mu \mathrm{m}$ in diameter (cf. Mastalerz \& Bustin, 1993; Chen et al. 2015). Carefully selected rodlets from marked sampling locations in the frond of Laveineopteris rarinervis (Table 1) were analyzed on a Nicolet 6700 spectrometer connected to a
Nicolet Continuum microscope that operated in reflectance mode to generate the data. The microscope was connected to a liquid, nitrogen-cooled mercury-cadmium-telluride (MCT) detector. MicroFTIR spectra were obtained at a resolution of $4 \mathrm{~cm}^{-1}$ over the range $4000 \mathrm{~cm}^{-1}$ to $600 \mathrm{~cm}^{-1}$ wavenumber, using a gold plate as background. An OMNIC program was used for processing the spectra. 
Table 1. Selection of sampled medullosalean compression fossils with rodlets in situ, Sydney Coalfield, Canada; bC = basal Cantabrian Sub-Stage, A = Austurian Sub-Stage. n.a. = not applicable.

\begin{tabular}{|c|c|c|c|c|}
\hline Taxon & $\begin{array}{l}\text { Specimen } \\
\text { length }\end{array}$ & $\begin{array}{c}\text { Rachial } \\
\text { order }\end{array}$ & $\begin{array}{c}\text { Accession } \\
\text { No. }\end{array}$ & $\begin{array}{c}\text { Age } \\
\text { (Coal seam) }\end{array}$ \\
\hline $\begin{array}{l}\text { Neuropteris ovata Hoffmann var. simonii } \\
\text { Bertrand, Zodrow \& Cleal } 1988 \text { (pl. 2) }\end{array}$ & $650 \mathrm{~mm}$ & 3 & $85-248$ & $\begin{array}{c}\mathrm{bC} \\
\text { (Point Aconi) }\end{array}$ \\
\hline $\begin{array}{l}\text { Alethopteris ambigua Lesquereux pars nov. } \\
\text { emend. Zodrow et Cleal } 1998 \text { (pl. 9) }\end{array}$ & $450 \mathrm{~mm}$ & 2 & $84-520$ & $\begin{array}{c}\mathrm{A} \\
(\mathrm{Hub})\end{array}$ \\
\hline $\begin{array}{l}\text { Alethopteris pseudograndinioides Zodrow } \\
\text { and Cleal } 1998 \text { (pl. 6) }\end{array}$ & $200 \mathrm{~mm}$ & 2 & $90-290 \mathrm{a}$ & $\begin{array}{c}\text { A } \\
\text { (Lloyd Cove) }\end{array}$ \\
\hline A. pseudograndinioides Zodrow 2007 (fig. 5) & $450 \mathrm{~mm}$ & 2 & $003-328 \mathrm{~A}$ & $\begin{array}{c}\text { A } \\
\text { (Gardiner) }\end{array}$ \\
\hline $\begin{array}{l}\text { Laveineopteris rarinervis (Bunbury) } \\
\text { nov. emend. Cleal et al. } 1990\end{array}$ & $450 \mathrm{~mm}$ & 2 & $002-295$ & $\begin{array}{c}\text { A } \\
\text { (Lloyd Cove) }\end{array}$ \\
\hline $\begin{array}{l}\text { Odontopteris cantabrica Wagner, Zodrow } 1985 \\
\text { (text-fig.12) }\end{array}$ & $400 \mathrm{~mm}$ & 3 & $80-281$ & $\begin{array}{c}\text { A } \\
\text { (Lloyd Cove) }\end{array}$ \\
\hline Medullosalean trunk in situ & $1300 \mathrm{~mm}$ & n.a. & $03-346$ & $\begin{array}{c}\text { A } \\
\text { (Lloyd Cove) }\end{array}$ \\
\hline Medullosalean upper stem & $350 \mathrm{~mm}$ & n.a. & 03-306 & $\mathrm{A}$ \\
\hline Medullosalean trunk? & $300 \mathrm{~mm}$ & n.a. & $02-309$ & $\mathrm{~A}$ \\
\hline Medullosalean, naked rachis & $850 \mathrm{~mm}$ & 4 & 05-Lst\#27 & $\mathrm{A}$ \\
\hline Medullosalean axis & $200 \mathrm{~mm}$ & n.a. & $06-06 / 22-5$ & $\mathrm{~A}$ \\
\hline Medullosalean petiole, bifurcating & $300 \mathrm{~mm}$ & n.a. & $03-7 / 10$ & $\mathrm{~A}$ \\
\hline
\end{tabular}

\section{RESULTS}

\section{Physical properties of rodlets}

Thickness of the vitrain in compression-preserved medullosalean specimens increases dramatically from pinnules to trunks, reflecting corresponding biomass increases of progressively larger frond parts, where reproductive organs are not considered, and biological degradation is assumed relatively minor prior to the anoxic plant burial. Additionally, the environment-favored preservation, as the fine-grained sediments comprising most of the roof rock minimized pore spaces thereby limiting oxygen diffusion from water influx in which the specimens were entombed (Allison, 1988). Our investigation demonstrated that even in the relatively thickest vitrain components of petioles and trunks, rodlets preserved strictly in the outermost coalified layer directly below, and in contact with, the cuticular component, which is particularly well illustrated for the naturally macerated pteridosperm Odontopteris cantabrica (Zodrow et al. 2012), e.g., Plate II, Fig. 1. Illustrated in Plate II, Fig. 2 is the main rachis of $A$. pseudograndinioides (cf. Plate I, Fig. 4) which has variably thick striae (rodlets) to suggest that thickness may not necessarily correlate with higher order of rachides. Moreover, rodlets tend to be invisible against the background of thinner compressions, and when favorable fossilization circumstances prevailed, maceration may reveal an association with elongate epidermal structures that are probably characteristic of higher-order rachides (Zodrow et al. 2017, Text-fig. $12 \mathrm{E})$.

The physical characteristics of the rodlet sample can collectively be best described in the following terms that the overall range of diameters is from $10-180 \mu \mathrm{m}$ and lengths up to $5,000 \mu \mathrm{m}$, which leaves open the question of natural length. Most were black and opaque, round overall with generally uneven or very twisted surfaces, and hence variable thicknesses along an individual rodlet; some were irregularly flattened, and a minority were crescentshaped. But in general, the brittleness of the rodlets posed problems for handling them.

Rodlets by association. Plate II, Fig. 3(A),(C) and (D) illustrate round rodlets, and (B) a rare crescent-shaped example which on this account resembles Fig. 21 of Lyons et al. (1982), though the latter has a much larger cross section. At the same time, and particularly (A) and (D) are twist- 
ed differentially resulting in variable diametric measurements, and whose uneven surfaces were the main factor that reduced the quality of the IR spectra, as planar surfaces are a prerequisite for reliable spectral data (see later).

Experimenting with high-light intensities on seemingly ordinary opaque and black fragmentary rodlets revealed a slight amber coloration, and an internal structural arrangement of oval-shaped, inclined light-colored spaces $2-3 \mu \mathrm{m}$ in size that are arranged en echelon at more or less regular intervals (e.g., Plate II, Fig. 4A). Kosanke et al. (1957, pl. 1, fig. 2) interpreted them as vesicles, or channeled, but not ruled out can be the possibility of entrapped palaeofluids (akin to fluid inclusions in crystals). However, some rodlets are naturally transparent as is illustrated in Plate II, Fig. 4B.

Parenthetically, a $34 \mu \mathrm{m}$ diameter, transparent and crescent-shaped rodlet was found in association with the foliage of Macroneuropteris scheuchzeri (Hoffmann) in a Ma-

zon Creek concretion (microslide PP31558/2b).

Rodlets in situ. These were comparatively more difficult to secure because protruding rodlets at the edge of rachial breakage could easily be fractured and lost. Also, solubility is a factor (see below). Nevertheless, Plate II, Fig. 5 shows in place on a penultimate-pinna rachis a fragmentary rodlet. A wide rodlet in situ of ca. $80 \mu \mathrm{m}$ diameter was extracted from the medullosalean trunk (Plate II, Fig. 6) that bore the largest-known frond segment $(65 \mathrm{~cm}$ ) of Neuropteris ovata (Zodrow and Cleal, 1988).

Rodlets either were or were not resistant to oxidation in Schulze's solution (4-6 $\mathrm{g}$ of potassium chlorate dissolved in non-fuming nitric acid), although most of the above referenced rodlets were not tested, some dissolved after about 1 hour and 15 minutes, leaving small amounts of dark residue of unknown composition, presumably inorganic.

\section{Chemical aspects}

Fourteen individual in situ rodlets from the rachides of the tripinnate specimen Laveineopteris rarinervis (see Table 1) were analyzed by microFTIR, and two supplied reliable, but limited, (i) qualitative and (ii) quantitative information that is summarized in Figure 2A and B. In our standard IR interpretations, e.g., Pšenička et al. (2013), or Zodrow \& Mastalerz (In press), (i) refers to assigning peaks to functional groups, as follows. The micro-FTIR spectra show prominent aromatic carbon bend at $1603 \mathrm{~cm}^{-1}$, and a very small shoulder at $1706 \mathrm{~cm}^{-1}$ which represents the carboxyl/carbonyl acid groups. Aromatic hydrogen bends are well expressed in the $900-700 \mathrm{~cm}^{-1}$ aromatic out-of-plane region, but they are indistinct in the aromatic stretching region of $3100-3000 \mathrm{~cm}^{-1}$, partly because of the high-noise level in the 4000 $-2000 \mathrm{~cm}^{-1}$ interval. There are distinct (but variable in intensity) aliphatic hydrogen bands in the 


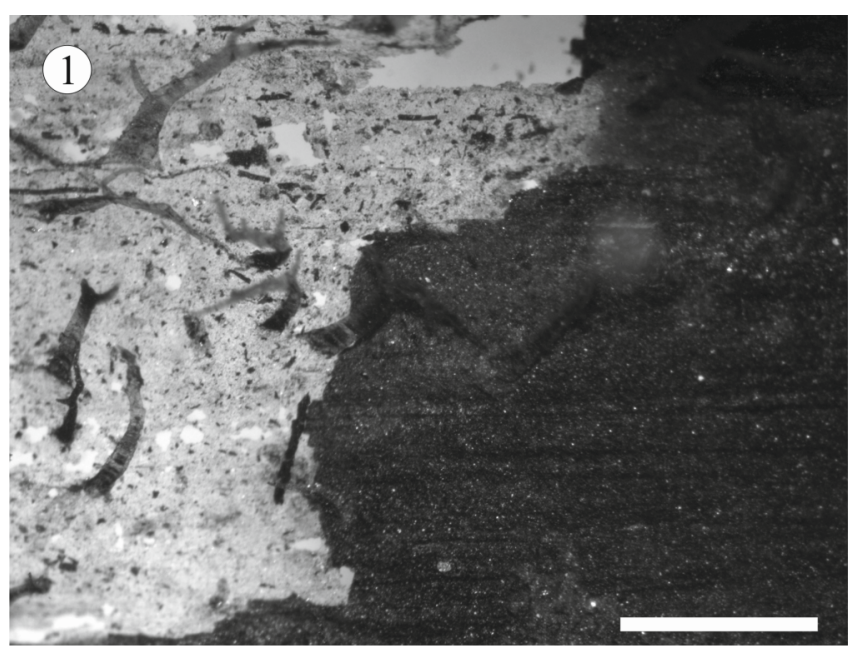

(3)
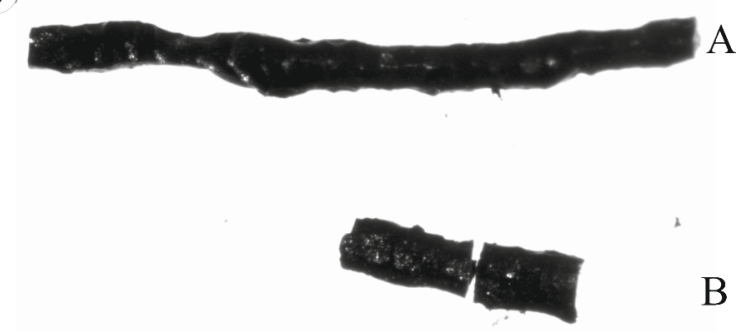

$\mathrm{B}$

$\mathrm{C}$

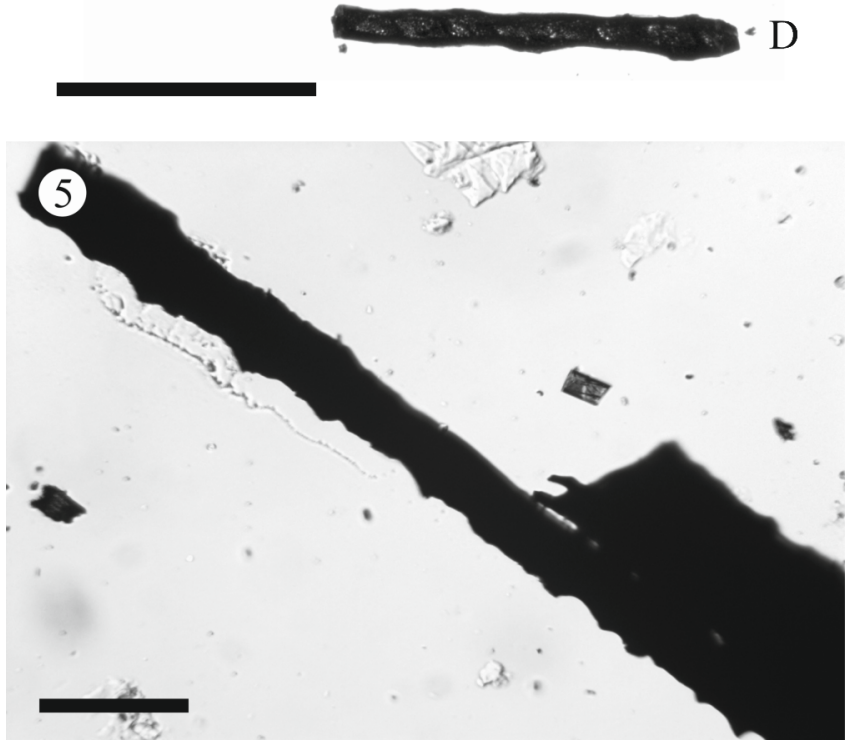

(2)

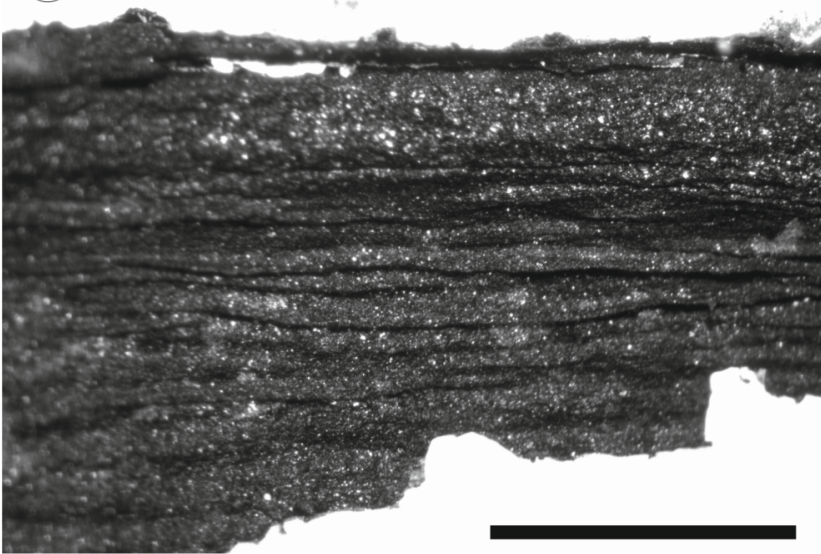

(4)

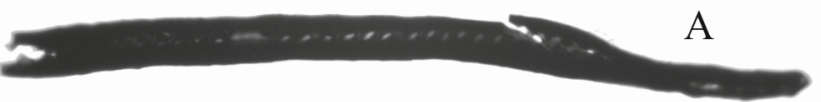

B
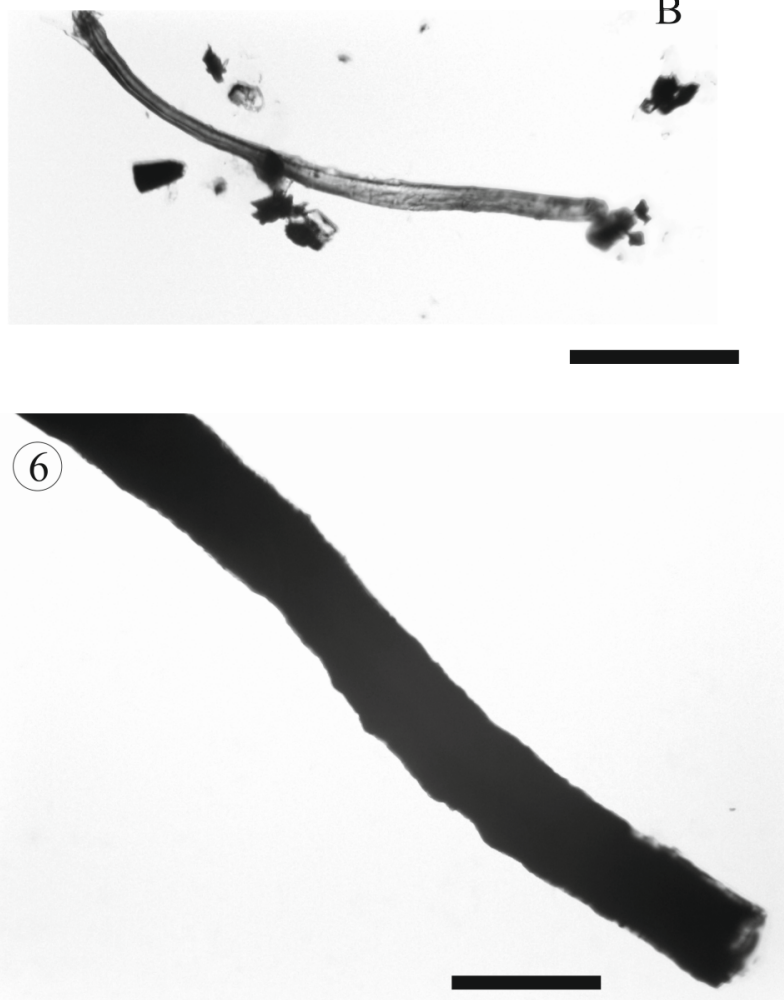

Plate II Rodlet samples selectively illustrated; 1) Adaxial main rachis with in situ rodlets and one loose one. Note the branching trichomes. See Table 1, 80-281, scale bar $2 \mathrm{~mm}$; 2) A. pseudograndinioides, main axis (Plate I, Fig. 4). 003-328A, scale bar $5 \mathrm{~mm}$; 3) Associate rodlets. See text, scale bar $0.65 \mathrm{~mm}$; 4) Associate rodlets. See text, scale bar $0.1 \mathrm{~mm}$; 5 ) Neuropteris ovata, secondary rachis, scale bar $0.1 \mathrm{~mm}$; 6) N. ovata, trunk (cf. Zodrow et al., 2016, fig. 2B), scale bar $0.1 \mathrm{~mm}$. 
$3000-2800 \mathrm{~cm}^{-1}$ region and aliphatic bending region with the peak at $1147 \mathrm{~cm}^{-1}$.

(ii) Refers to mathematical manipulation of the digitized spectra to calculate functional- group ratios. In the present case, this is limited to deconvolution in the $3000-2800 \mathrm{~cm}^{-1}$ region, where some aliphatic bands were distinct, and calculated were the two aliphatic $\mathrm{CH}_{2} / \mathrm{CH}_{3}$ ratios, although below unity, i.e., 0.85 and 0.73 , they are deemed reliable values. Nevertheless, this is significant information about the relatively short and branched aliphatic hydrocarbon chains that can be deduced from the comparatively low values which are consistent with the aromatic nature of the rodlets (cf. Pšenička et al., 2013, Figure 4). These values, for example, are increasingly used as efficient phytochemical-classification parameters to separate plant-fossil groups (not species) such as true ferns from seed ferns, as hypothesized already by Zodrow \& Mastalerz (2002, table 3).

\section{CONCLUDING REMARKS}

The significance of the invariable presence of rodlets in the medullosalean-frond samples in general likely correlates with the biomechanical property of 'strength' they contribute to stabilize the huge medullosalean tree-ferns. Based on this reasoning, rodlets are unimportant (absent?) from bush-type medullosaleans like Odontopteris minor Brongniart that were ca. $50 \mathrm{~cm}$ tall, according to Zeiller (in Potonié, 1903, fig. 3).

Thus, the present study fills an important knowledge gap for Carboniferous plant fossils by demonstrating the origin of an insoluble type of refractory rodlets from coalified fronds, rachides, and trunks.

However, distinguishable from these rodlets are other types. These include (1) the transparent and the 'channeled', and (2) the soluble rodlets whose botanical functions in these fronds remain to be explored by future work, presumably involving thin-sectioning combined with focused ion-beam microscopy (TEM/FIB) (Benedetti et al., 2016), and other advanced methods to refine the chemistry.

Despite the high-noise level caused by very uneven rodlet surfaces, the two IR spectra suggest relatively high aromaticity and low aliphatics which are similar to functional groups of aromatic fusinite (cf. Lyons et al. 1982), or secretinite macerals (cf. Lyons \& Mastalerz (2001) who also used microFTIR techniques but cautioned about the aliphatic- chain interpretation because of low absorbance of aliphatic bands in their spectra.

In summary, we can unequivocally state that (a) the reported aliphatic ratios are the lowest in our extensive FTIR data base, and that (b) that the combination of low contents of aliphatics and high contents of aromatics in the insoluble rodlets from the Laveinopteris rarinervis frond (002-295) differentiate them from the vitrinite coal and the cuticle-free compression of Macroneuropteris scheuchzeri, which are all from the Lloyd Cove Seam (Zodrow et al. 2014, table 2; Lyons et al. 1995,table 3, fig. 10).

This would suggest that rodlets are chemically different and probably represent an undetermined chemical group, with implications for molecular taxonomy of medullosalean seed ferns.

\section{ACKNOWLEDGEMENT}

We thank K. Martha Jones (Biology Department, Cape Breton University, Sydney, Nova Scotia, Canada) for the use of research microscopes.

\section{REFERENCES}

Allison, P.A. 1988. The role of anoxia in the decay and mineralization proteinaceous macro-fossils. Paleobiology 14, 139-154.

Beeler, H.E. 1983. Anatomy and frond architecture of Neuropteris ovata and N. Scheuchzeri from the Upper Pennsylvanian of the Appalachian Basin. Canadian Journal of Earth Sciences 61, 2352-2368.

Benedetti, A., Diez, J.B., Sender, L.M. Cunéo, R. 2016. New application of FIB: a 3D look into the past throughout the ultrastructure of fossil plant cuticles. Microscopy and Microanalysis. doi: 10.1017/S1431927616000234

van Bergen, P.F., Collison, M.E., Scott, A.C., de Leeuw, J.W. 1995. Unusual resin chemistry from Upper Carboniferous pteridosperm resin rodlets. In Amber, Resinite, and Fossil Resins (Anderson, K.B. and Crelling, J.C. eds.). ACS Symposium Series 617, Washington, D.C., pp. 149-169. Chen Yanyan, Zou Caineng, Mastalerz, M., Suyun $\mathrm{Hu}$, Gasaway, C., Toa Xiaowan. 2015. Applications of micro-Fourier Transform Infrared spectroscopy (FTIR) in the geological sciences A review. International Journal of Molecular Sciences 15, 30223-30255, doi 10.3390. 
Cleal, C.J., Shute, C.H., Zodrow, E.L. 1990. A revised taxonomy for Palaeozoic neuropterid foliage. Taxon 39, 486-492.

D’Angelo, J.A., Zodrow, E.L. 2018. Biomechanical models of Alethopteris ambigua and Neuropteris ovata (Late Pennsylvanian, Canada): implications for chemometrics and fossil classification. MS.

Kosanke, R.M., Harrison, J.A. 1957. Microscopy of the resin rodlets of Illinois coal. Circular 234. Illinois State Geological Survey, Urbana, 1-14

Lyons, P.C., Orem, W.H., Mastalerz, M., Zodrow, E.L., Vieth-Redeman, A., Bustin, R.M. $1995 .{ }^{13} \mathrm{C}$ NMR, micro-FTIR and fluorescence spectra of coalified foliage of late Carboniferous medullosan seed ferns, Nova Scotia, Canada: Implications for coalification and chemotaxonomy. International Journal of Coal Geology 27, 227-248.

Lyons, P.C., Mastalerz, M. 2001. Secretinite - reflectance and chemical data from two hight volatile bituminous coals (Upper Carboniferous) of North America. International Journal of Coal Geology 45, 281-287.

Lyons, P.C., Finkelman, R.B., Thompson, C.L., Brown, F.W., Hatcher, P.G. 1982.Properties, origin and nomenclature of rodlets of the inertinite maceral group in coals of the central Appalachian basin, USA. International Journal of Coal Geology 1, 313-346.

Mastalerz, M., Bustin, R.M. 1993. Electron microprobe and micro-FTIR analyses applied to maceral chemistry. International Journal of Coal Geology 24, 333-345.

Potonié, H. 1903. Abbildungen und Beschreibung fossiler Pflanzenreste der palaeozoischen und mesozoischen Formationen. Lieferung I. 13. Königlich Preussischen Geologischen Landesamt, Berlin, p. 1-6.

Pšenička, J. Zodrow, E.L., D’Angelo, J.A., 2013. Sterile foliage of fertile Sydneia manleyi and synangial chemistry (Eusporangiate fern, Late Asturian, Canada): A new Subfamily Sydneideae. Folia Musei Rerum Naturalium Bohemiae Occidentalis: Geologica et Paleobiologica, 47(1-2), 1-13. Raymond, A. Phillips, T.L. 1983. Evidence for an Upper Carboniferous Mangrove Community. In Biology and Ecology of Mangroves, ed. H.J. Teas, pp. 188, Springer Verlag, p. 19-30.

Steidtmann, W.E. 1944. The anatomy and affinities of Medullosa noei Steidtmann, andassociated foliage, roots, and seeds. University of Michigan Press Ann Arbor,VI(7) pp. 131-166

Zodrow, E.L. 1985. Odontopteris Brongniart in the Upper Carboniferous of Canada. Palaeontographica B 196, 79-110.

Zodrow, E.L. 2007. Reconstructed tree fern Alethopteris zeilleri (Carboniferous, Medullosales). International Journal of Coal Geology 69, 68-89.

Zodrow, E.L., Cleal, C.J. 1988. The structure of the Carboniferous pteridosperm frond Neuropteris ovata Hoffmann. Palaeontographica B, 208, 105-124.

Zodrow, E.L., Cleal, C.J. 1998. Revision of the pteridosperm foliage Alethopteris and Lonchopteridium (Upper Carboniferous), Sydney Coalfield, Nova Scotia, Canada. Palaeontographica B, 247, 65-122.

Zodrow, E.L., Mastalerz, M. 2002. FTIR and pyGC-MS spectra of true-fern and seed-fern sphenopterids (Sydney Coalfield, Nova Scotia, Canada, Pennsylvanian). International Journal of Coal Geology 51, 111-127.

Zodrow, E.L., Mastalerz, M. (In press). Functional groups of trichomes on the seed fern Odontopteris cantabrica: Implications for molecular taxonomy. Bulletin of Geosciences.

Zodrow, E.L., Tenchov, Y.G., Cleal, C.J. 2007. The arborescent Linopteris obliqua plant (Medullosales, Pennsylvanian). Bulletin of Geosciences 82, 51-84.

Zodrow, E.L., Mastalerz, M., Werner-Zwanziger, U., D'Angelo, J.A. 2010. Medullosalean fusain trunk from the roof rocks of a coal seam: Insight from FTIR and NMR (Pennsylvanian Sydney Coalfield, Canada). International Journal of Coal Geology 82, 116-124.

Zodrow, E.L., D’Angelo, J.A., Helleur, R., Šimůnek, J., 2012. Functional groups and common pyrolysates products of Odontopteris cantabriaca (index fossil for the Cantabrian Substage, Carboniferous). International Journal of Coal Geology 100, 40-50.

Zodrow, E.L., D’Angelo, J.A., Werner-Zwanziger, U., Banghao Chen. 2014. Hair-trichomes-files, and spectrochemistry of Macroneuropteris scheuchzeri (Basal Cantabrian, Sydney Coalfield, Canada). Palaeontographica B 290, 141-153.

Zodrow, E.L., D'Angelo, J.A., Cleal, C.J. 2017. 3D chemometric model and frond architecture of Alethopteris ambigua (Medullosales): Implications for reconstruction and taxonomy. Palaeontographica B 295, 91-133. 